\title{
Electricity Generation by Enterobacter $s p$. of Single-Chamber Microbial Fuel Cells at Different Temperatures
}

\author{
Olga Tkach, Lihong Liu, and Aijie Wang
}

\begin{abstract}
Practical applications of microbial fuel cells (MFCs) for wastewater treatment will require operation of these systems over a wide range of temperatures. MFCs at room or higher temperatures $\left(20-35^{\circ} \mathrm{C}\right)$ are relatively well studied compared those at lower temperatures. MFC performance was examined here over a temperature range of $5-25^{\circ} \mathrm{C}$ in terms of initial time needed for reproducible power cycles, and performance. We have investigated the Enterobacter $s p$. ALL-3 at the different temperatures and it was it was found more effective if the microorganism is able to transfer electrons directly (exo-electrogenic organism) via the cytochromes or the ubiquinone. These carriers of electrons form stable reversible redox couples, not biologically degraded and not toxic to cell. MFCs was originally launched at $10^{\circ} \mathrm{C}$, followed by a decrease in temperature to $5^{\circ} \mathrm{C}$ and then the temperature was increased to $25^{\circ} \mathrm{C}$, thus we have created the conditions to the natural fluctuations in temperature. This cell performance resembled that for MFC operated at $5^{\circ} \mathrm{C} \mathrm{(30} \mathrm{d).} \mathrm{That} \mathrm{for} \mathrm{MFC} \mathrm{operated} \mathrm{at}$ $10^{\circ} \mathrm{C}$ voltage of reactors increased to $525-530 \mathrm{mV}$, just after 8-10 days level decreased to $<50 \mathrm{mV}$. A subsequent increase in temperature up to $25^{\circ} \mathrm{C}$ led to the fact that the voltage in the reactor dropped to $480 \mathrm{mV}$, but remained still high. The cycle has increased to 12-d. These results demonstrate that MFCs can effectively be operated over a wide range of temperatures, but our findings have important implications for the startup of larger scale reactors where low wastewater temperatures could delay or prevent adequate startup of the system.
\end{abstract}

Index Terms-Cyclic voltammetry, Enterobacter sp., microbial fuel cells, microbiological identification, polarization curve, power generation.

\section{INTRODUCTION}

Energy has become an inevitable source for this modern world and fossil fuel is the main source for our energy needs. Fossil fuel is exhausted and therefore, we have to come up with new ideas for sustainable development. One of such methods will be receiving electricity from bacteria through the using of microbial fuel cell. Microbial fuel cells (MFC) can convert the chemical energy of organic matter into electric energy with the using of microorganisms, providing a method of simultaneous production of renewable energy

Manuscript received October 15, 2014; revised January 17, 2015. This work was supported in part by the U. S. Department of Commerce under Grant BS123456: Electricity generation by Enterobacter sp. of single-chamber microbial fuel cells at different temperatures.

Olga Tkach, Lihong Liu, and Aijie Wang are with the State Key Laboratory of Urban Water Resources and Environments (SKLUWRE), School of Municipal and Environmental Engineering, Harbin Institute of Technology, Haerbin 150090, China (e-mail: tsyganovahelga@gmail.com, Lihongliu0405@163.com,waj0578@hit.edu.cn). during wastewater treatment [1]-[4].

Bacteria gain energy by the transferring electrons from an electron donor (glucose or acetate) to an electron acceptor (oxygen). The larger the difference in potential between donor and acceptor the bigger growth of the organism which can proportionally affect on the columbic efficiency and on the electricity generation. Hence microbial fuel cells are used of potential microbial energy to generate electricity.

There is the organism inoculated in pure or in mixed culture of the microbial fuel cell [5]. The yield of electricity is overwhelming in case of microbial fuel cell inoculated with the mixed culture. The product of one organism has been made useful by others [6]. For example Pseudomonas aeruginosa in a mixed consortium, produces pyocyanin and several more shuttling compound which are used by other electrochemically active organisms for electron transferring. But there are also some major setbacks with this approach which predominately includes the risk of contamination.

The microbial fuel cell is broadly classified as mediator less microbial fuel cell and mediator fuel cell. The mediator less microbial fuel cell is found to be more effective as the microorganism is able to transfer electrons directly (exoelectrogenic organism) via the cytochromes or the ubiquinone. These carriers of electrons are in form of stable reversible redox couples, not biologically degraded and not toxic to cell [7], [8]. Examples of such bacteria are Geobacter [9], [10] and Rhodoferax ferrireducens [11]. Further the sediments from eroded beds (marine as well as lake bed) have the consortia of exo-electrogenic organism [12]. These organisms have been reported to form biofilms on the electrode surface.

Power density produced by bacteria with pure compounds such as acetate has increased by nearly six orders of magnitude through improvements in reactor architecture [13], [14], optimization of solution chemistry [2], [15], and using new materials and modifying electrode surfaces [16], [17], [7], [18]. Characteristics of the substrates and system operation also can greatly affect power densities. These include solution pH [19], [20]; wastewater alkalinity, added buffers and their concentration, ionic strength, and solution conductivity [21], [15]; operation mode in terms of fed-batch or continuous flow [1], [22]; and specific organic matter species in the different types of wastewater and their degradation by products [2], [21] [23], [24].

Temperature is another important characteristic, but the most studies have examined performance at a single temperature, with typical temperatures chosen of room temperature or higher $\left(20-35^{\circ} \mathrm{C}\right)$. When temperatures have 
been varied during a study, different results have been obtained relative to impact of temperature on performance, although in almost all cases lowering the temperature reduced performance. In two different studies with single-chamber MFCs operated in fed-batch mode, the power density decreased by $10 \%$ when the temperature was reduced from $32^{\circ} \mathrm{C}$ to $20^{\circ} \mathrm{C}$ [15], [25]. In another study with a single-chamber MFC operated with continuous mode, the power density decreased by $21 \%$ when the temperature decreased from $35^{\circ} \mathrm{C}$ to $24^{\circ} \mathrm{C}$, but only by $5 \%$ when the temperature was decreased from $30^{\circ} \mathrm{C}$ to $24^{\circ} \mathrm{C}$ [26].

Bacteria, such as Enterobacter aerogenes (E. aerogenes) [27], Escherichia coli (E. coil) [28] и Clostridium butyricum [29], [30] may not act as catalysts for the production of electricity, thus, additional chemical catalyst is always required for oxidation of hydrogen, most of platinum $(\mathrm{Pt})$. Interestingly, Zhang et al. (2006) reported that E. coli-catalyzed MFC with not-Pt anode was able to produce a maximum power density more than $600 \mathrm{mWm}^{2}$, assuming direct Biocatalysis for electricity production is possible with the help of E. coli.

Although there were lots of researches done on the basement of big variety bacteria and yeast for microbial fuel cells but almost no work was done in pure culture for fuel cell application, using Enterobacter cloacae. In this study we examined the performance of single-chamber MFC insulinaemia bacteria Enterobacter sp. in the range of working temperatures $5-25^{\circ} \mathrm{C}$. We compared the performance of the system in these various initial temperatures, with the consequent increase of temperature by the following parameters of voltage, current and power density, and cyclic voltammetry.

\section{MATERIALS AND METHODS}

\section{A. Microbial Fuel Cell Construction and Operation}

The single-chamber MFC includes an anode and cathode which are placed into bilateral water-tube column, presented by camera made of polypropylene in diameter of $6 \mathrm{~cm}$ and in length of $7 \mathrm{~cm}$ with an efficient working volume in $110 \mathrm{ml}$.

The anode was presented by carbon brush $(40 \mathrm{~mm}$ in diameter and $40 \mathrm{~mm}$ in length; T700- $12 \mathrm{~K}$, Toray Industries Co. Ltd., Japan). The cathode was presented by carbon cloth (W0S1002, CoTech Co., Ltd., $19.6 \mathrm{~cm}^{2}$ ) with the water side coated with carbon black (Vulcan XC-72) and the catalyst $\left(0.5 \mathrm{mg} / \mathrm{cm}^{2} \mathrm{Pt}\right)$ mixed with a Nafion binder, and the air side with four PTFE diffusion layers for preventing water leakage [17], [31]. Electrodes were connected from external side with concealed copper wire by dint of external load resistance

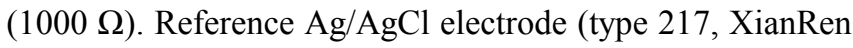
Industries Co., Shanghai, China) was installed into the anodic chamber for conducting of electrochemical measurements. Prior to construction for MFC, $70 \% \mathrm{C}_{2} \mathrm{H}_{5} \mathrm{OH}$ was completely filled in chambers for 1 day to guarantee complete sterilization [32]. After sterilization, chamber was cleaned up by deionized-and-distilled water and all reactors were autoclaved before inoculation into chamber. All tests were performed in duplication by means of two sets with use of same equipment, performance and filling.

\section{B. Inoculation and Growth Media}

The activated sludge was taken from the Harbin Wenchang Wastewater Treatment Plant. This sludge was adapted into an acetate medium for electricity generation by seed bacterial cultures. They were taken from activated sludge and were pre-cultured in PBS medium containing $2 \mathrm{~g} / \mathrm{L}$ acetate for 2 months. Half of microbial culture broth was replaced with fresh medium every 5 days to maintain maximal metabolic activity of bacterial cells. PBS medium contained (per liter) $\mathrm{NaAc} 2.0 \mathrm{~g}, \mathrm{NH}_{4} \mathrm{Cl} 0.62 \mathrm{~g}, \mathrm{KCl}, 0.26 \mathrm{~g}, \mathrm{NaH}_{2} \mathrm{PO}_{4} 4.9 \mathrm{~g}$, $\mathrm{Na}_{2} \mathrm{HPO}_{4} 9.15 \mathrm{~g}$, mineral solution $12.5 \mathrm{ml}$, and Wolfe's vitamin solution $5 \mathrm{ml}$, with $\mathrm{pH}$ adjusted to 7.0.

Then, cultured microbial cells were added into MFCs for cell propagation after 2-months their pre-culturing. At the same time, in MFC, half of the medium in the reactor was replaced by fresh medium when cell voltage was dropped to $50 \mathrm{mV}$. The MFC system was considered as ready for under steady-state operation when its maximum voltage output was stable and reproducible after three cycles of medium replacement.

\section{Electrochemical Analysis}

The cells voltage was measured automatically (setting at one data point per minute) through an acquisition data system (DAS 5020; Jiehan Technology Corporation) for external resistance Rout $=125 \mathrm{mV}$. The power of density $(\mathrm{P})$ for MFC of fed-batch mode could be calculated as per Eq. (1):

$$
P=\frac{U I}{\text { Area }}
$$

where, $U$ is the voltage between anode and cathode (V), $I$ is the current (A), Area is denoted as an anode area (19.625 $\left.\mathrm{cm}^{2}\right)$

The evaluation of voltammetry by linear sweeping (LSV) was performed with a potentiometer/galvanometer (CHI 440, $\mathrm{CH}$ Instrument Inc., Austin, TX, USA). The voltage and current were recorded by LSV at a scan rate of $1 \mathrm{mV} / \mathrm{s}$. The value of output power was calculated as Vcell $\times$ Icell. The density of current and density of power were calculated on cathodic area base $\left(19.6 \mathrm{~cm}^{2}\right)$. For analysis of electrochemical response the system of three electrodes was prepared in (for) the anode compartment. The curves of polarization, namely, the density of current against the potential (vs. $\mathrm{Ag} / \mathrm{AgCl} / \mathrm{sat}$ 'd $\mathrm{KCl}$ ) were obtained by LSV at a scan rate of $1 \mathrm{mV} \mathrm{s}^{-1}$.

The electrochemical impedance spectroscopy (EIS) experiments were performed at the end of tests. "ZahnerTM IM6ex" potentiostat-AC frequency analyzer equipment was used for the EIS experiments, and the results were analyzed with using of "Thales1" software. The frequency of the AC signal was varied from $100 \mathrm{kHz}$ to $10 \mathrm{mHz}$ with an amplitude of $5 \mathrm{mV}$.

An impedance experiment was performed under galvanostatic closed circuit conditions at $400 \mathrm{~mA}$ for the mature biofilms. The initial electrical potential for anode tests was at $\mathrm{p} 0.5 \mathrm{~V}$, while that for cathode tests it was at p $0.25 \mathrm{~V}$. To ensure steady state during galvanostatic operation, the MFCs were allowed to equilibrate for $10 \mathrm{~min}$ between each of current setting before applying the AC signal. 
Cyclic voltammetry (CV) was carried out using a potentiometer (CHI 627C; $\mathrm{CH}$ instrument, USA) connected to a personal computer (CHI627C Electrochemical Analyzer) with a scan rate of $0.1 \mathrm{~V} \mathrm{~s}^{-1}$, ranging from -0.45 to $0.6 \mathrm{~V}$. A conventional three-electrode set-up was employed, with the anode as the working electrode, an $\mathrm{Ag} / \mathrm{AgCl}$ reference electrode, and platinum wire as the counter electrode. $\mathrm{CV}$ is a standard tool in electrochemistry, and could provide valuable insight into the electron transfer interactions between microorganisms or microbial biofilms and microbial fuel cells Hence, voltammograms were obtained during a period of maximum current generation to detect the electrochemical properties of the MFCs.

\section{Microbiological Isolation and 16S rRNA Phylogenetic Analysis}

The rationale to isolate dominant electrochemically active strain(s) is straightforward as follows: dispersing of the sample; isolating the developed colonies, and finally, conducting isolate identification via SDS-PAGE (sodium dodecyl sulphate-polyacrylamide gel electrophoresis) and 16S rRNA gene analysis [32]. Microbial samples obtained from the well-propagated biofilm on the anode of MFCs were first used to isolate the predominant bacteria for bioelectricity generation. Isolated samples were then spread onto the solidified agar medium containing iron-containing culture medium contained (per liter) $\mathrm{NaHCO}_{3} 2.5 \mathrm{~g}, \mathrm{NH}_{4} \mathrm{Cl} 1.5 \mathrm{~g}$, $\mathrm{KH}_{2} \mathrm{PO}_{4} 0.6 \mathrm{~g}, \mathrm{KCl} 0.1 \mathrm{~g}$, yeast extract $0.01 \mathrm{~g}$, ferric citrate $12.28 \mathrm{~g}$, acetate $0.82 \mathrm{~g}$ with $\mathrm{pH}$ adjusted to 6.8 and plates were cultivated at $10^{\circ} \mathrm{C}$ for the propagation of colonies. This procedure of strain isolation through agar plates was carried out at least three times to ensure the purity of isolates. After screening upon the most dominant isolates (e.g., large-sized colonies) via SDS-PAGE, protein spectra (i.e., translation profiles) of these isolates were found all similar to be possibly genetically identical.

The bacterial 16S rRNA gene clone libraries were constructed by using universal primer sets $27 \mathrm{~F}$ (50-AGAGTTTGATCC TGGCTCAG-30) and 1492R (50-GGTTACCTTGTTACGACTT-30). PCR- amplification was performed following the below conditions: $5 \mathrm{~min}$ of denaturation at $94^{\circ} \mathrm{C}$, followed by 35 cycles at $94^{\circ} \mathrm{C}$ for $45 \mathrm{~s}$, $55^{\circ} \mathrm{C}$ for $45 \mathrm{~s}$ and $72^{\circ} \mathrm{C}$ for $90 \mathrm{~s}$, with a final extension at $72^{\circ} \mathrm{C}$ for $10 \mathrm{~min}$. The PCR products were purified on a $1 \%$ agarose gel, extracted with a UNIQ-10 gel-extraction kit (Shanghai Sangon Biological Engineering Technology \& Services Co., Ltd., Shanghai, China), then ligated to vector pMD19 and cloned into Enterobacter sp. DH5a competent cells following the manufacturer's protocol. Hundred plasmids containing positive insert from this sample were sequenced using an $\mathrm{ABI}$ 3730XL sequencer (Applied Biosystems, Foster, CA) with 27F primer. 16S rRNA gene Sequences were analyzed using the "BLASTN", search tools (http://www.ncbi.nlm.nih.gov/blast) and 'EzTaxon" server [33]. Alignments with different $16 \mathrm{~S}$ rRNA gene sequences from GenBank were performed using "Clustal X' 1.8 .3 with default settings. The phylogenetic characteristics were analyzed with "MEGA' version 4.0 software, and distances were calculated using the "Kimura 2", parameter distance model, also. A phylogenetic tree was built using by the neighbor-joining method. Each of dataset was bootstrapped over 1000 times [34].

The microstructure of the biofilm on the anode surface was examined using scanning electron microscopy (SEM, JSM-6330F, JEOL, Tokyo, Japan). The SEM samples were pretreated following the procedure described by Zhang et al. (2008).

\section{RESULTS AND DISCUSSION}

\section{A. MFCs Performance}

Voltage-t curves cell performances at various temperatures reactor is shown in Fig. 1. As seen in Fig. 1, voltage reactors has increased, to a maximum of $500 \mathrm{mV}$ during feeding, after 8-10 days its level was reduced to $<50 \mathrm{mV}$. The maximum stress level was stable up to $500 \mathrm{mV}$ and maintained around that value after all acetate was consumed. This cell performance resembled that for MFC operated at $5^{\circ} \mathrm{C}(30 \mathrm{~d})$. That for MFC operated at $10^{\circ} \mathrm{C}$ voltage of reactors increased to $525-530 \mathrm{mV}$, just after 8-10 days level decreased to $<50$ $\mathrm{mV}$. A subsequent increase in temperature up to $25^{\circ} \mathrm{C}$ led to the fact that the voltage in the reactor dropped to $480 \mathrm{mV}$, but remained still high. The cycle has increased to 12-d.

As the result of research we found that the change of temperature does not greatly effect on changes in indicators of power. But the best results of stable power for the production of the original operating temperatures we have managed to achieve at $10^{\circ} \mathrm{C}$. It is important that we have found that if the MFCs started up at the lowest temperatures of $5^{\circ} \mathrm{C}$ and $10^{\circ} \mathrm{C}$ it did not produce an appreciable power even after very long operation times. This shows that the initial temperature has great impact on the initial formation of an exoelectrogenic biofilm. This shows that, once formed, the bacteria were able to operate at different temperatures.

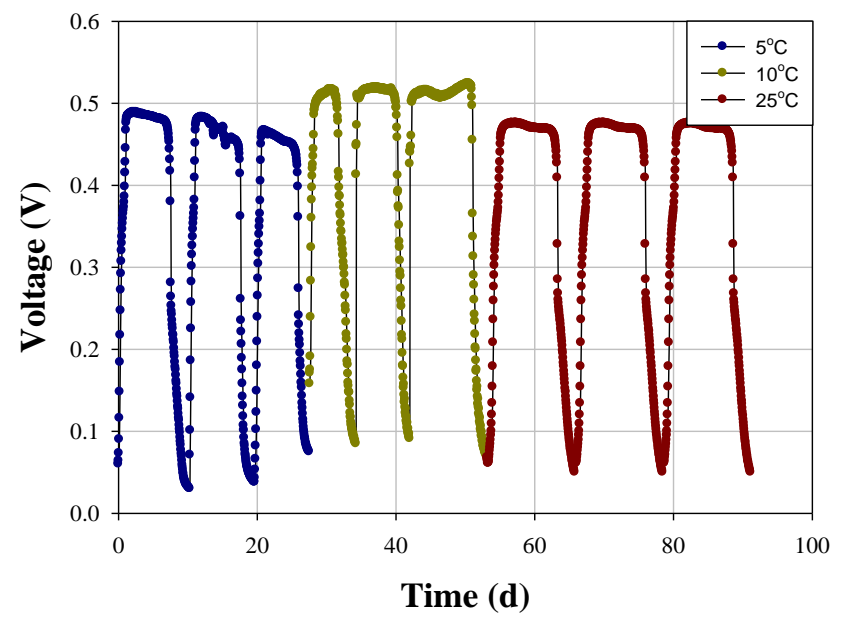

Fig. 1. Cell performances at different temperatures.

\section{B. Electrode Characteristics}

The main characteristics of MFCs are presented at Table I. All these parameters were calculated by voltage and power density charts which were produced by different reactors and are shown at Fig. 2. 
TABLE I: COMBINED ELECTRODES CHARACTERISTICS OF EXAMINED MFCS (PAGE 4, ELECTRODE CHARACTERISTICS)

\begin{tabular}{ccccccc}
\hline Activation & $\begin{array}{c}\text { Open-circle } \\
\text { voltage }\end{array}$ & $\begin{array}{c}\text { Maximum power } \\
\text { density }\end{array}$ & $\begin{array}{c}\text { Current at maximum } \\
\text { power density }\end{array}$ & $\begin{array}{c}\text { Voltage at maximum } \\
\text { power density }\end{array}$ & $\begin{array}{c}\text { Short } \\
\text { circuit } \\
\text { current } \\
\text { density }\end{array}$ \\
$\boldsymbol{C}$ & losses & $(\mathbf{m V})$ & $\left(\mathbf{m W} / \mathbf{m}^{\mathbf{2}}\right)$ & $\left(\mathbf{A} / \mathbf{m}^{\mathbf{2}}\right)$ & $(\mathbf{m V})$ & $\left(\mathbf{A} / \mathbf{m}^{\mathbf{2}}\right)$ \\
\hline $\mathbf{5}$ & $\mathbf{m V})$ & 100 & 293 & 0.29 & 79 & 0.424 \\
$\mathbf{1 0}$ & 180 & 200 & 213 & 1.45 & 147 & 2.26 \\
$\mathbf{2 5}$ & 157 & 168 & 84 & 0.66 & 126 & 0.95 \\
\hline
\end{tabular}

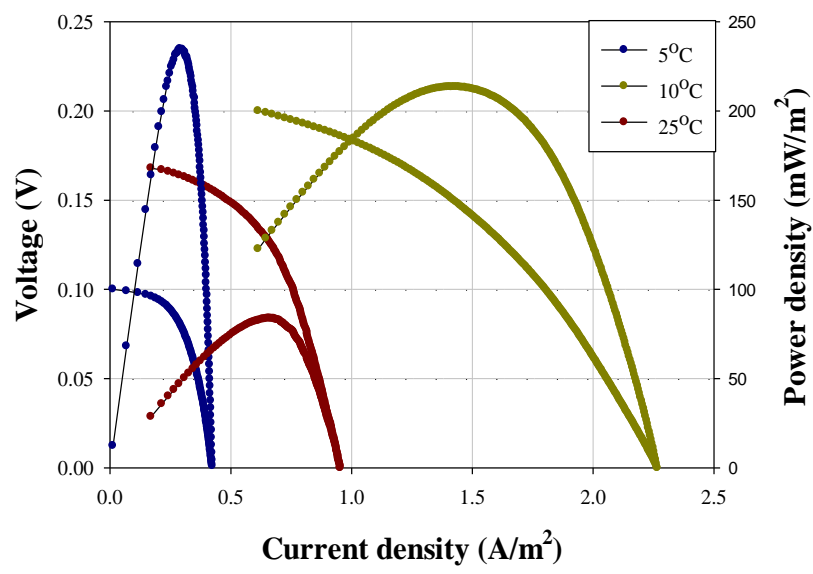

Fig. 2. Polarization curve and power density curve at different temperatures.

For MFC $5^{\circ} \mathrm{C}$ the open-circle voltage $(\mathrm{OCV})$ was $100 \mathrm{mV}$. Reducing of external load yielded an increase in electrical current with reduction of cell voltage. The mild initial drop in voltage indicates the presence of activation losses for the present MFC at approximately $90 \mathrm{mV}$. When the reaching was $V=79 \mathrm{mV}$ and $I=0.29 \mathrm{Am}^{-2}$, the power of density peaked at $243 \mathrm{mWm}^{-2}$. It was found, that further decreasing in external loading reduces the power of density. The density of short circuit current $\left(\mathrm{I}_{\mathrm{scc}}\right)$ was $0,424 \mathrm{Am}^{-2}$. No cell power shoot how it was proposed by Nien et al. [35], [36] and it was noted for the present MFC.

For MFC $10^{\circ} \mathrm{C}$ the open-circle voltage (OCV) was $200 \mathrm{mV}$. The mild initial drop in voltage indicates the presence of activation losses for the present MFC at approximately 184 $\mathrm{mV}$. When reaching was $V=147 \mathrm{mV}$ and $I=1.45 \mathrm{Am}^{-2}$ the power of density peaked at $213 \mathrm{mWm}^{-2}$. Also, it was found that further decreasing in external loading reduces the power density as in the previous group. The density of short circuit current $\left(\mathrm{I}_{\mathrm{scc}}\right)$ was $2.26 \mathrm{Am}^{-2}$.

For MFC $25^{\circ} \mathrm{C}$ the open-circle voltage (OCV) was $168 \mathrm{mV}$. The mild initial drop in voltage indicates the presence of activation losses for the present MFC at approximately 157 $\mathrm{mV}$. When the reaching was $V=126 \mathrm{mV}$ and $I=0.66 \mathrm{Am}^{-2}$, the power of density peaked at $84 \mathrm{mWm}^{-2}$. It was investigated as in others previous cases that further decreasing in external loading reduced the power of density. The density of short circuit current $\left(\mathrm{I}_{\mathrm{scc}}\right)$ was $0.95 \mathrm{Am}^{-2}$.

The main characteristics of MFCs are presented at Table I.

\section{Cyclic Voltammetry $(\mathrm{CV})$}

$\mathrm{CV}$ was performed to characterize the electrochemical activity of the anodic biofilm. Fig. 3 gives the $\mathrm{CV}$ results for the anode in the E. sp.ALL-3-MFC. The measurements of cyclic voltammetry (CV) both of redox activities of components in anodic medium and mediators bound to the bacterial in anodic chamber were evaluated. $\mathrm{CV}$ was performed in the anode medium with pure bacteria culture.

After 15 days $\mathrm{MFC} 5^{\circ} \mathrm{C}$ operation, the voltammogram recorded a strong oxidation peak at $0.4 \mathrm{~V}$ (vs. SCE) in the forward scan and a strong reduction two peaks at 0.45 and $0.12 \mathrm{~V}$ (vs. SCE) in the reverse scan, indicating electrochemical activity of the biofilm on the anode surface. It appears that under long-term electrochemical tension, E.sp. ALL-3 grew on or became attached on the anode to form a biofilm and developed a capability for electrochemical activity. After the temperature in the reactor was raised to $10^{\circ} \mathrm{C}$ another dimension $\mathrm{CV}$ was recorded an oxidation peak at $0.39 \mathrm{~V}$ in the forward scan and a reduction two peaks at 0.38 and $0.16 \mathrm{~V}$. When the temperature in the reactor has raised up to $25^{\circ} \mathrm{C}$ there was an increase of peak current in an oxidation peak at $0.4 \mathrm{~V}$ in the forward scan with the reduction of two peaks, on minor at 0.42 and $0.18 \mathrm{~V}$. These results are indicating the electrochemical activities bacteria and the presence of redox active compounds in the anode biofilm, which may be involved in extracellular process of electrons transfer.

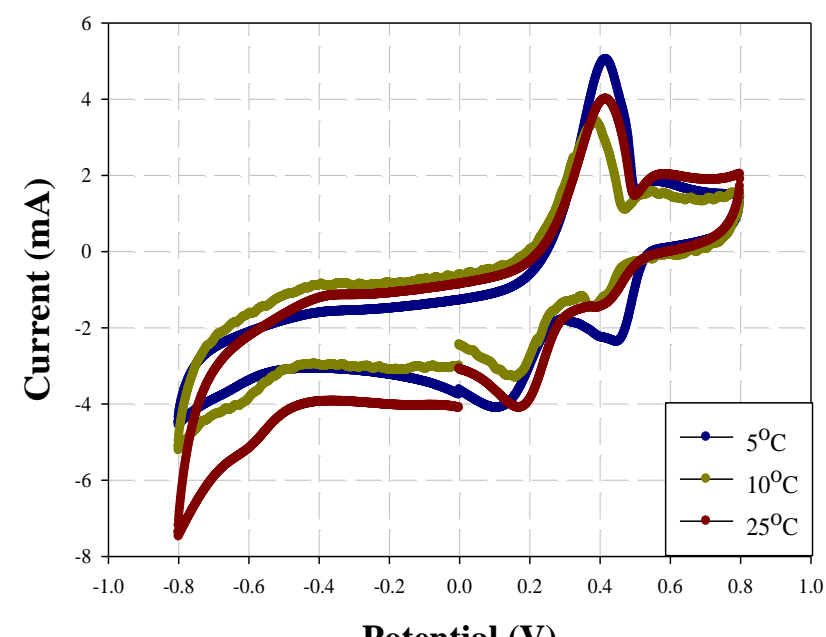

Potential (V)

Fig. 3. Cyclic voltammograms for different temperatures.

\section{Culture Isolation Studies}

After all the tests on completion of work, at which point a piece of carbon brush in the anode was sampled and analyzed under a scanning electron microscope. The cells in the anodic biofilm have tiny wires $(20-50 \mathrm{~nm})$ connecting it, to provide the conducting paths for enhancing electron transfer to anode surface (Fig. 4). The anode MFC was covered with bacterial cells long rods. Apparently, the SEM observation further demonstrated the formation of a biofilm structure on the electrode surface over a short period of time.

Fig. 6 shows the morphological characteristics of the strain, long rod, weeks flagella, no capsule, long $2-4 \mu \mathrm{m}$. 

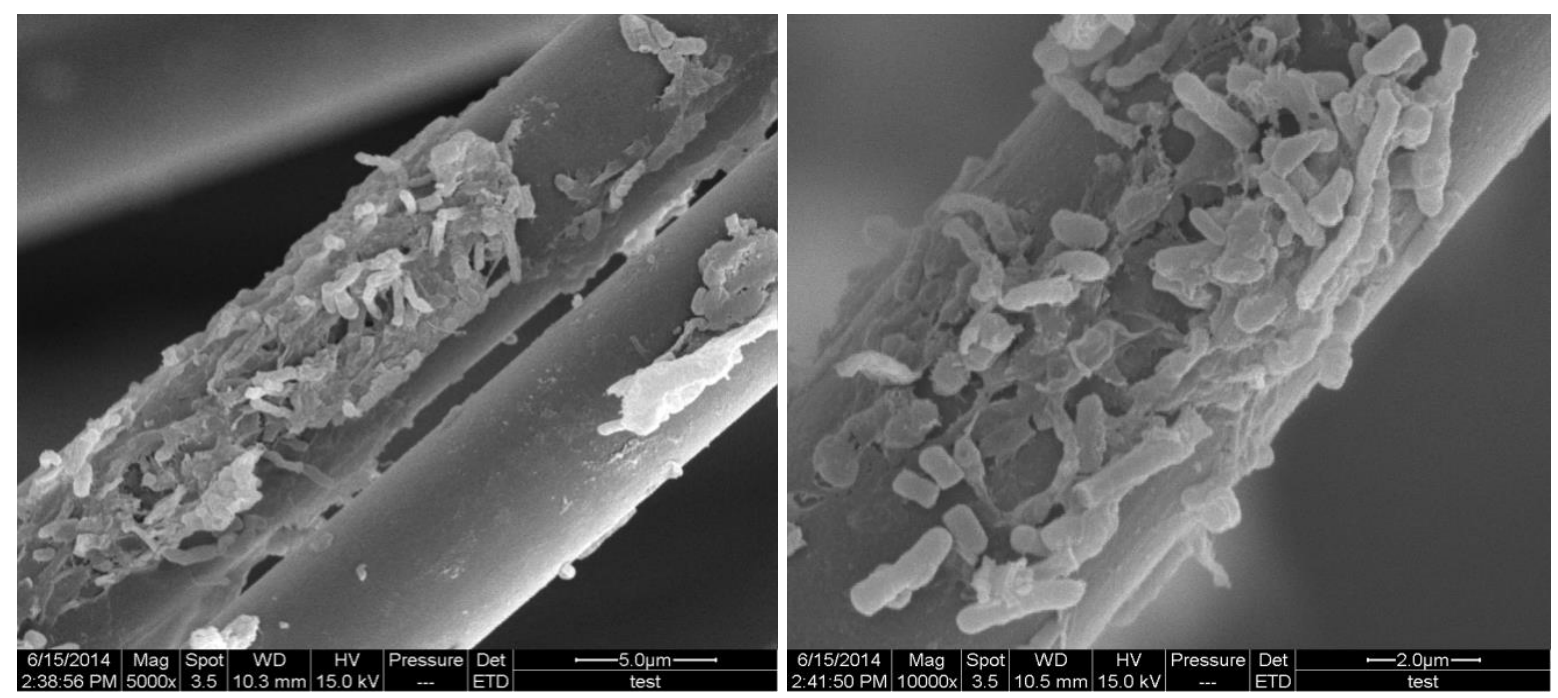

Fig. 4. SEM photographs for anodic biofilms at the end of tests.

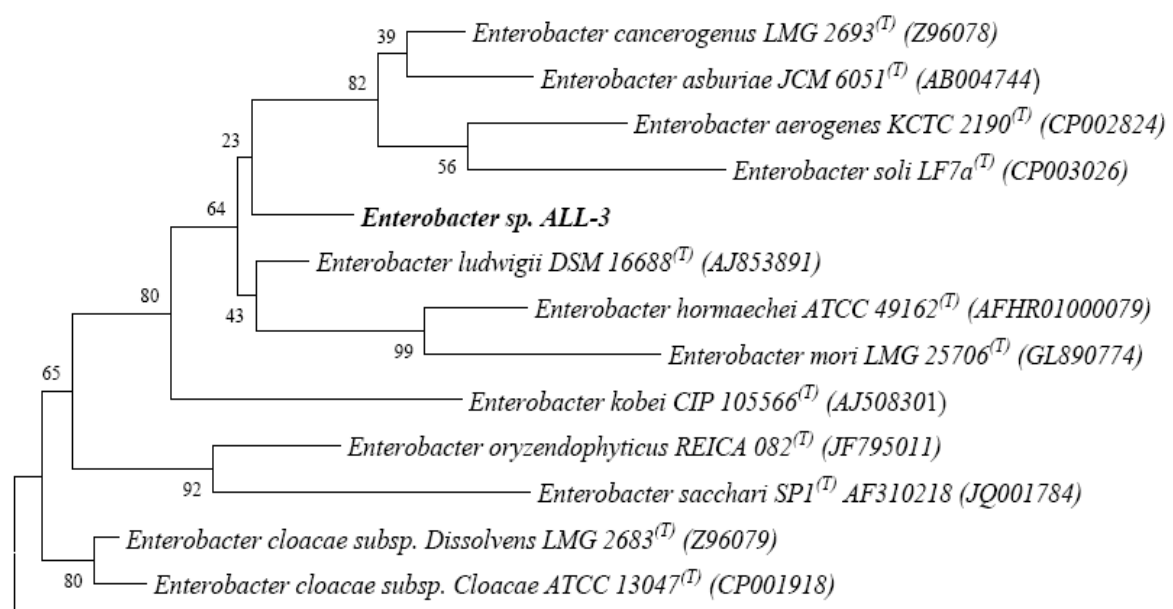

Enterobacter siamensis C2361 (I) $($ HQ888848)

Fig. 5. Enterobacter sp ALL-3, based on the 16S rDNA sequences of Enterobacteriacae showing the phylogenetic position of the isolated strain (page 5, Culture isolation studies).
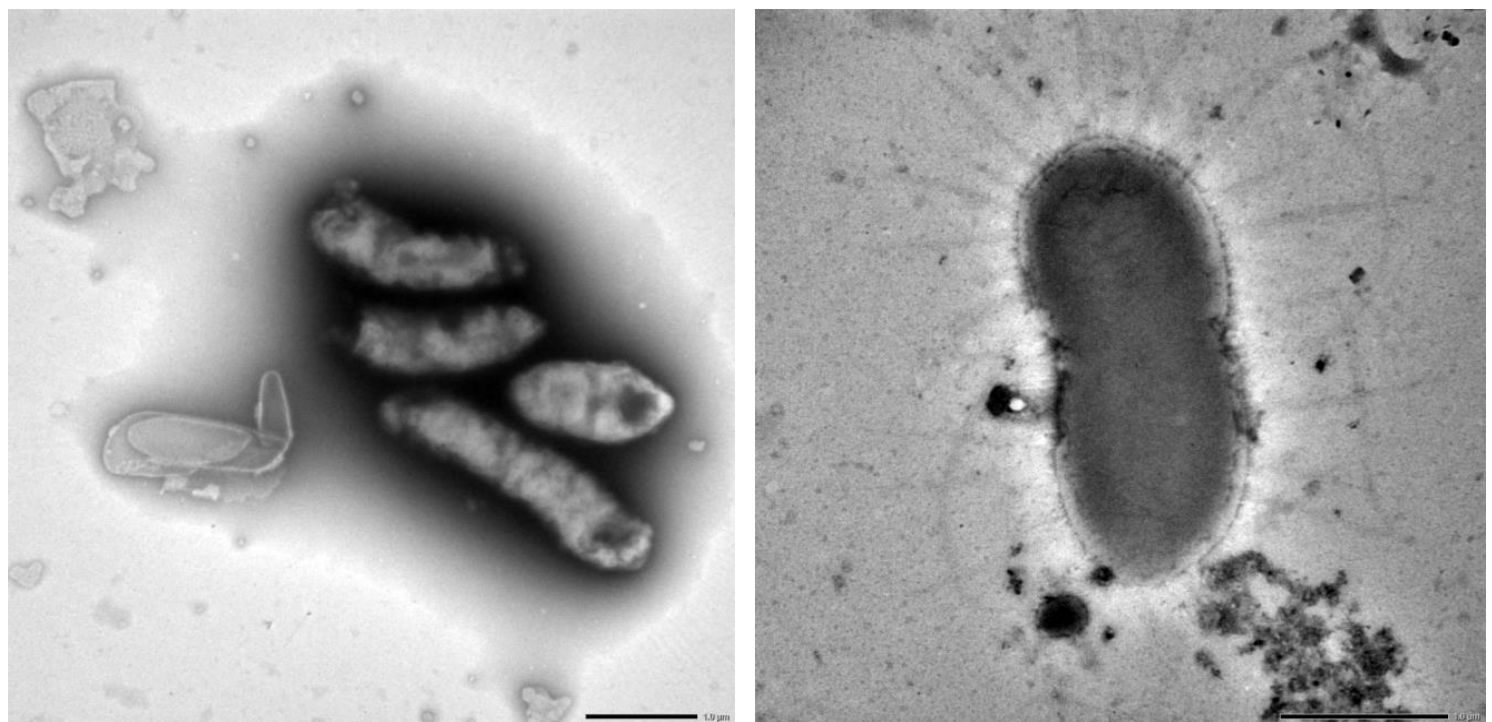

Fig. 6. TEM photographs for anodic biofilms at the end of tests.

The 16S rRNA gene clone libraries for anodic biofilm of MFC yielded 30 operational taxonomic units (OTUs), and that for anodic biofilm of MFC produced 32OTUs based on100 random selected clone sequences (Table II). The ribotypes were identified phylogenetically and were grouped by phylum. The total frequency for a given phylogenic group was calculated.

Enterobacter $s p$. ALL-3 was isolated with activated sludge 
taken from the Harbin Wenchang Wastewater Treatment Plant and identified by $16 \mathrm{~s}$ rRNA sequence. Enterobacter sp. ALL-3 was maintained in minimal agar medium. 16S rRNA gene sequencing was carried out to identify the isolated strain and the 1037 bp sequence was determined. Based on the similarity of the $16 \mathrm{~S}$ rRNA gene, the isolate was found to be analogous to Enterobacter ludwigii DSM 16688 (99.53\%), Enterobacter cloacae subsp. Dissolvens LMG 2683 (99.25\%), Enterobacter cloacae subsp. Cloacae ATCC 13047 (99.13\%) and Enterobacter cancerogenus LMG 2693 (99.05\%). A phylogenetic tree was constructed and it is shown in Fig. 5. The isolate was determined to belong to E. sp. based on the results of 16S rRNA gene sequencing, and was designated, Enterobacter sp. ALL-3 (GenBank accession number: $\mathrm{KC} 211019)$. The numbers at the nodes indicate the levels of bootstrap support based on a neighbor-joining analysis of 1000 resampled datasets: only the values $\geq 99 \%$ are given.

TABLE II: SimILARITY OF THE 16S RRNA GENE SEQUENCES OBTAINED FROM ClONE LIBRARY OF ANODE BRUSH AND THEIR CLOSELY MATCHED SPECIES. (PAge 5, Culture Isolation Studies)

\begin{tabular}{|c|c|c|c|c|}
\hline Name & Accession & Similarity $(\%)$ & Diff/Total nt & Ref \\
\hline Enterobacter ludwigii DSM $16688^{(T)}$ & AJ853891 & 99,53 & $7 / 1478$ & {$[1]$} \\
\hline $\begin{array}{l}\text { Enterobacter cloacae subsp. Dissolvens } L M G \\
2683^{(T)}\end{array}$ & Z96079 & 99,25 & $11 / 1476$ & {$[2]$} \\
\hline Enterobacter cloacae subsp. Cloacae ATCC $13047^{(T)}$ & CP001918 & 99,13 & $13 / 1498$ & {$[3]$} \\
\hline Enterobacter cancerogenus LMG $2693^{(T)}$ & Z96078 & 99,05 & $14 / 1471$ & {$[4]$} \\
\hline Enterobacter asburiae JCM $6051^{(T)}$ & AB004744 & 98,95 & $15 / 1422$ & {$[5]$} \\
\hline Enterobacter hormaechei ATCC $49162^{(T)}$ & $\begin{array}{l}\text { AFHR0100007 } \\
9\end{array}$ & 98,6 & $21 / 1498$ & [6] \\
\hline Enterobacter aerogenes KCTC $2190{ }^{T)}$ & $\mathrm{CP} 002824$ & 98,4 & $24 / 1498$ & [7] \\
\hline Enterobacter oryzendophyticus REICA_082 ${ }^{(T)}$ & JF795011 & 98,36 & $23 / 1404$ & {$[8]$} \\
\hline Enterobacter kobei CIP $105566^{(T)}$ & AJ508301 & 98,28 & $25 / 1450$ & [9] \\
\hline Enterobacter soli $L F 7 a^{(T)}$ & CP003026 & 98,2 & $27 / 1498$ & [10] \\
\hline Enterobacter mori LMG $25706^{(T)}$ & GL890774 & 98,2 & $27 / 1498$ & {$[11]$} \\
\hline Enterobacter sacchari SP1 $1^{(T)}$ & JQ001784 & 97,53 & $37 / 1497$ & [12] \\
\hline Enterobacter siamensis $C 2361^{(T)}$ & HQ888848 & 97,06 & $42 / 1429$ & {$[13]$} \\
\hline
\end{tabular}

\section{CONCLUSION}

It was shown that the production of electricity using MFC with pure culture Enterobacter sp. ALL-3 was under the strong influence of environment temperature. MFC achieved reproducible production of electricity at temperature of $10^{\circ} \mathrm{C}$, as it was temperature the minimum operation cycle. For MIFC, which produces power at each temperature, the amount of power was not proportional to the temperature. Maximum peaks power of density and cyclic voltammetry were observed at a temperature of $5^{\circ} \mathrm{C}$.

\section{ACKNOWLEDGMENT}

The authors gratefully acknowledge funding from Project 51176037 supported by National Nature Science Foundation of China and partial supports by State Key Laboratory of Urban Water Resource and Environment, Harbin Institute of Technology.

\section{REFERENCES}

[1] Y. Ahn and B. E. Logan, "Effectiveness of domestic wastewater treatment using microbial fuel cells at ambient and mesophilic temperatures," Bioresour. Technol. vol. 101, no. 2, pp. 469-475, 2009.

[2] Y. Feng, X. Wang, B. E. Logan, and H. Lee, "Brewery wastewater treatment using air-cathode microbial fuel cells," Appl. Microbiol. Biotechnol. vol. 78, no. 5, pp. 873-880, 2008.

[3] H. Liu and B. E. Logan, "Electricity generation using an air-cathode single chamber microbial fuel cell in the presence and absence of a proton exchange membrane," Environ. Sci. Technol. vol. 38, no. 14, 4040-4046, 2004.
[4] B. Min and B. E. Logan, "Continuous electricity generation from domestic wastewater and organic substrates in a flat plate microbial fuel cell," Environ. Sci. Technol., vol. 38, no. 21, pp. 5809-5814, 2004.

[5] V. N. Sharma and M. Abhilasha, "Bioelectricity generation from paper industry waste using a microbial fuel cell by Clostridium species," $J$ Biochem Tech, vol. 1, no. 2, pp. 4-52, 2009.

[6] K. Rabaey, N. Boon, S. D. Siciliano, M. Verhaege, and W. Verstraete "Biofuel cells select for microbial consortia that self-mediate electron transfer," Appl Environ Microbiol, vol. 70, no. 9, pp. 5373-5382, 2004.

[7] D. H. Park and J. G. Zeikus, "Improved fuel cell and electrode designs for producing electricity from microbial degradation," Biotechnol Bioeng, vol. 81, no. 3, pp. 348-355, 2003.

[8] I. Willner, E. Katz, F. Patolsky, and A. F. Buckmann, "Biofuel cell based on glucose oxidase and microperoxidase-11 monolayerfundionalized electrodes," J. Chem. Soc. Perkin Trans, vol. 2, no, 8, pp. 1817-22, 1998.

[9] D. R. Bond and D. R. Lovley, "Electricity production by Geobacter sulfurreducens attached to electrodes," Appl. Environ Microbiol., vol. 69, no. 3, pp. 1548-1555, 2003.

[10] H. Yi, K. P. Nevin, B. C. Kim, A. E. Franks, A. Klimes, L. M. Tender et al., "Selection of a variant of Geobacter sulfurreducens with enhanced capacity for current production in microbial fuel cells," Biosens Bioelectron, vol. 24, no. 12, pp. 3498-3503, 2009.

[11] S. K. Chaudhuri and D. R. Lovley, "Electricity generation by direct oxidation of glucose in mediatorless microbial fuel cells," Nat Biotechnol, no. 21, pp. 1229-1232, 2003.

[12] L. M. Tender, C. E. Reimers, H. A. Stecher, D. E. Holmes, D. R. Bond, D. A. Lowy et al., "Harnessing microbially generated power on the seafloor," Nat Biotechnol, vol. 20, no. 8, pp. 821-825, 2002.

[13] B. E. Logan and J. M. Regan, "Electricity-producing bacterial communities in microbial fuel cells," Trends Microbiol., vol. 14, no. 12, pp. 512-518, 2006.

[14] B. E. Logan and J. M. Regan, "Microbial fuel cells - Challenges and applications," Environ. Sci. Technol. 2006b, vol. 40, no. 17, pp. 5172-5180. 
[15] H. Liu, S. Cheng, and B. E. Logan, "Power generation in fed-batch microbial fuel cells as a function of ionic strength, temperature, and reactor configuration," Environ. Sci. Technol., vol. 39, no. 14, pp. 5488-5493, 2005

[16] S. Cheng and B. E. Logan, "Ammonia treatment of carbon cloth anodes to enhance power generation of microbial fuel cells," Electrochem. Commun., vol. 9, no. 3, pp. 492-496, 2007.

[17] B. E. Logan, S. Cheng, V. Watson, and G. Estadt, "Graphite fiber brush anodes for increased power production in air-cathode microbial fuel cells," Environ Sci Technol., vol. 41, no. 9, pp. 3341-3346, 2007.

[18] F. Zhang, S. Cheng, D. Pant, G. V. Bogaert, and B. E. Logan, "Power generation using an activated carbon and metal mesh cathode in a microbial fuel cell," Electrochem. Commun., vol. 11, no. 11, pp. 2177-2179, 2009.

[19] A. P. Borole, H. O’Neill, C. Tsouris, and S. Cesar, "A microbial fuel cell operating at low $\mathrm{pH}$ using the acidophile Acidiphilium cryptum," Biotechnol. Lett., vol. 30, pp. 1367-1372, 2008.

[20] Y. Fan, E. Sharbrough, and H. Liu, "Quantification of the internal resistance distribution of microbial fuel cells," Environ. Sci. Technol., vol. 42, no. 21, pp. 8101-8107, 2008 .

[21] L. Huang and B. E. Logan," Electricity generation and treatment of paper recycling wastewater using a microbial fuel cell," Appl. Microbiol. Biotechnol., vol. 80, no. 2, pp. 349-355, 2008a.

[22] L. Huang and B. E. Logan," Electricity production from xylose in fed-batch and continuous-flow microbial fuel cells," Appl. Microbiol. Biotechnol., vol. 80, no. 4, pp. 655-664, 2008b.

[23] H. Liu, R. Ramanarayanan, and B. E. Logan, "Production of electricity during wastewater treatment using a single chamber microbial fuel cell," Environ. Sci. Technol., vol. 38, no. 7, pp. 2281-2285, 2004

[24] B. Min, J. R. Kim, S. Oh, J. M. Regan, and B. E. Logan, "Electricity generation from swine wastewater using microbial fuel cells," Water Res., vol. 39, no. 20, pp. 4961-4968, 2005.

[25] X. Wang, Y. Feng, and H. Lee," Electricity production from beer brewery wastewater using single chamber microbial fuel cell," Water Sci. Technol., vol. 57, no. 7, pp. 1117-1121, 2008.

[26] H. Moon, I. S. Chang, and B. H. Kim, "Continuous electricity production from artificial wastewater using a mediator-less microbial fuel cell," Bioresour. Technol., vol. 97, no. 4, pp. 621-627, 2008.

[27] S. Tanisho, N. Kamiya, and N. Wakao, "Microbial fuel cell using Enterobacter aerogenes," Bioelectrochem. Bioenerg., vol. 21, pp. 25-32, 1989.

[28] U. Schröder, J. Nieben, and F. Scholz, "A generation of microbial fuel cells with current outputs boosted by more than one order of magnitude," Angew. Chem. Int. Ed., no. 42, pp. 2880-2883, 2003.

[29] J. Niessen, U. Schröder, F. Harnisch, and F. Scholz, "Gaining electricity from in situ oxidation of hydrogen produced by fermentative cellulose degradation," Lett. Appl. Microbiol., no. 41, pp. 286-290, 2005.

[30] J. Niessen, U. Schröder, and F. Scholz, "Exploiting complex carbohydrates for microbial electricity generation - A bacterial fuel cell operating on starch," Electrochem. Commun., vol. 6, pp. 955-958, 2004.

[31] S. A. Cheng, H. Liu, and B. E. Logan, "Increased performance of single-chamber microbial fuel cells using an improved cathode structure," Electrochem. Commun., vol. 8, pp. 489-494, 2006.

[32] B. Y. Chen, W. M. Chen, F. L. Wu, P. K. Chen, and C. Y. Yen, "Revealing Azo-dye decolorization of indigenous aeromonas hydrophila from fountain spring in Northeast Taiwan," J. Chin. Inst. Chem. Eng., vol. 39, p. 495, 2008.

[33] J. Chun, J. H. Lee, Y. Jung, M. Kim, S. Kim, B. K. Kim, et al. "EzTaxon: a web-based tool for the identification of prokaryotes based on 16Sribosomal RNA gene sequences," Int J Syst Evol Microbiol, vol. 57, pp. 2259-2261, 2007.

[34] K. Tamura, J. Dudley, and M. Nei, "MEGA4: molecular evolutionary genetics analysis (MEGA) software version 4.0.," Mol Biol Evol, vol. 24, pp. 1596-1599, 2007.

[35] P. C. Nien, C. Y. Lee, K. C. Ho, L. H. Liu, A. J. Wang, N. Q. Ren et al., "Power overshoot in two-chambered microbial fuel cells (MFC)," Bioresour Technol, vol. 102, pp. 4742-4746, 2011.
[36] L. H. Liu, C. Y. Lee, K. C. Ho, P. C. Nien, A. Su, A. J. Wang et al. "Occurrence of power overshoot for two-chambered MFC at nearly steady-state operation," Int. J. Hydrogen Energy, vol. 36, pp. 13896-13899, 2011.

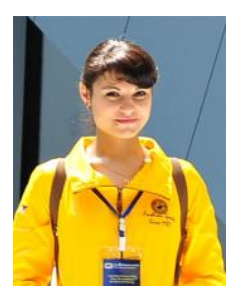

Olga Tkach was born in Kansk town in the Krasnoyarsk region in Russia on October 1, 1982. In 2002 she finished her study in Kansk Medical College and got the specialty "Medical assistant". Then she has graduated from Krasnoyarsk State Pedagogical University named after V. P. Astafjev and got profession "Teacher of Chemistry with additional specialty Biology" in 2008 in the Krasnoyarsk city, Russia. In 2008 she has entered in the Postgraduate School of Harbin Technological University on the "Modern environmental system and engineering" in Harbin, China.

In 2008 she worked as a chemistry teacher in the Kansk Lycee. In 2007 2008 she worked as a medical assistant in the medical center "The formula of health". In 2007 she worked as a laboratory assistant of biochemical field in the Krasnoyarsk State Pedagogical University named after V.P. Astafjev. In 2002-2003 she worked as a medical assistant in the Kansk Psychoneurological Dispensary. Nowadays, she has studied in the Post Graduate School of Harbin Technological University in Harbin, China Fields of her scientific interests are ecological problems, environmental system, alternative energy sources, biofuel, microbial fuel cells.

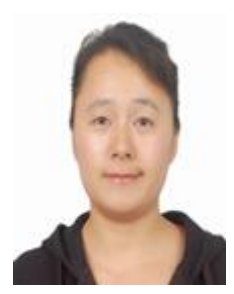

Lihong Liu joined the Department of Geochemistry, School of Earth Sciences, Northeast Petroleum University, Daqing, China in July, 2014. Her academic experiences are below, from July 2014 until now, she is a lecturer in Northeast Petroleum University. She was pursuing her $\mathrm{PhD}$ degree from September 2008 to June 2014 in School of Municipal and Environmental Engineering, Harbin Institute of Technology, Harbin, China. She received her MS degree in June 2008 form M.S. Dept. of Biology, Harbin Normal University, Harbin, China. She received her BS degree June 2004, form B.S. Dept. of Biology, Mudanjiang Normal University, Mudanjiang, China.

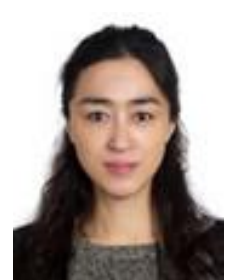

Aijie Wang is a recipient of National Outstanding Youth Science Fund Award and One Hundred Talent Program Award (CAS), a distinguished professor of Yangtze River Scholar, Ministry of Education of China. She obtained her Ph.D degree in 2000 in environmental engineering at Harbin Institute of Technology, China. Her research interests cover the theory and application of resources recovery from waste(water)/biosolids, e.g. Novel Technology for wastewaters biotreatment and wastes-to-bioresouces, Bioelectrochemical stimulated technology for recalcitrant compounds biodegradation, Organic wastes (excess sludge, waste biomass, etc.) cascade utilization to recover bioresources and/or bioenergy, -Omices based understanding of microbial function in engineered system. She has been granted 3 National Science and Technology Awards, and 6 Provincial Science and Technology Awards for her contributions in the field of wastewater biotreatment and wastes-to-resources. Aside from this, she has published more than 90 papers in reputed journals and 4 monographs in Science Press, and over 20 National Invention Patents. She is the Head of Key Laboratory of Environmental Biotechnology, CAS. She serves as a board member of Management Committee in IWA AD Specialist Group (Representitve of Asia Area), an ASM Ambassador to the China and an adjunct professor in Oklahoma University, USA. 